\title{
PEMANFAATAN LIMBAH RAMI (Boehmeria nivea) SEBAGAI BAHAN COMPLETE FEED TERHADAP KONSUMSI DAN KECERNAAN IN VIVO PADA KAMBING PERANAKAN ETAWA BETINA LEPAS SAPIH
}

\section{THE INFLUENCE OF RAMIE (Boehmeria nivea) WASTE AS A COMPLETE FEED COMPONENT ON CONSUMPTION AND IN VIVO DIGESTIBILITY OF ETTAWA CROSSBRED WEANED GOAT}

\author{
Emmy Susanti* dan Fransisca Maria Suhartati \\ Fakultas Peternakan, Universitas Jenderal Soedirman, Purwokerto, 53123
}

Submitted: 19 December 2014, Accepted: 29 September 2015

\section{INTISARI}

Penelitian ini bertujuan untuk mengetahui pengaruh complete feed menggunakan limbah rami dengan atau tanpa fermentasi serta sumber protein nabati atau hewani terhadap konsumsi dan kecernaan in vivo pada kambing Peranakan Etawah (PE) betina lepas sapih. Penelitian disusun dengan rancangan pola faktorial 2x2 dengan 6 (enam) ulangan. Faktor pertama merupakan complete feed tanpa dan dengan fermentasi dan faktor kedua adalah sumber protein. Hasil penelitian menunjukkan bahwa pengaruh penggunaan limbah rami sebagai bahan complete feed terhadap teknologi fermentasi tidak berbeda nyata terhadap konsumsi bahan kering (BK), bahan organik (BO), protein kasar (PK), neutral detergent fiber (NDF), dan acid detergent fiber (ADF). Pemberian sumber protein nabati $(34,64 \pm 3,47 \mathrm{~g} / \mathrm{kg}$ BB) secara nyata lebih tinggi terhadap konsumsi BK dibandingkan dengan sumber protein hewani $(32,24 \pm 5,85 \mathrm{~g} / \mathrm{kg} \mathrm{BB})$, tetapi secara nyata menurunkan konsumsi ADF dengan protein nabati $(10,65 \pm 1,85 \mathrm{~g} / \mathrm{kg} \mathrm{BB})$ dibandingkan dengan protein hewani $(10,82 \pm 1,53 \mathrm{~g} / \mathrm{kg} \mathrm{BB})$. Perlakuan fermentasi berpengaruh pada kecernaan in vivo NDF dan ADF yaitu berturut-turut $43,50 \pm 4,92 \%$ dan $25,92 \pm 2,02 \%$ tanpa fermentasi menjadi $32,58 \pm 3,31 \%$ dan $45,50 \pm 6,15 \%$ dengan fermentasi. Perlakuan sumber protein nabati $(53,17 \pm 2,35 \%)$ menunjukkan kecernaan in vivo BK secara nyata lebih tinggi dari pada sumber protein hewani $(50,83 \pm 2,68 \%)$. Interaksi kedua perlakuan tidak berbeda pada konsumsi tetapi berbeda nyata pada kecernaan in vivo PK dan ADF. Kesimpulan dari penelitian ini adalah kambing PE betina lepas sapih yang mendapat complete feed menggunakan limbah rami fermentasi menunjukkan penurunan kecernaan in vivo NDF, sebaliknya meningkatkan kecernaan in vivo ADF. Pemberian complete feed menggunakan limbah rami dengan sumber protein hewani menurunkan konsumsi BK, menaikkan konsumsi NDF dan menurunkan kecernaan in vivo BK sedangkan interaksi kedua perlakuan berpengaruh pada kecernaan PK dan ADF.

(Kata kunci: Fermentasi, Kecernaan in vivo, Konsumsi, Rami, Sumber protein)

\section{ABSTRACT}

The aim of research was to know the influence of ramie waste with and without fermentation as of plant or animal protein source on the consumption and in vivo digestibility of Etawah cross (PE) female weaned goat. Research was designed with factorial $2 \times 2$ and six (6) times replication. First factor was complete feed with and without fermentation and second factor was protein source. The result of ramie waste on fermentation prosessing was descented no effect on dry matter (DM), organic matter (OM), crude protein (CP), NDF and ADF consumption. The effect of added plant protein source was to promote DM consumption $(34.64 \pm 3.47 \mathrm{~g} / \mathrm{kg} \mathrm{BW})$ than with animal protein $(32.24 \pm 5.85 \mathrm{~g} / \mathrm{kg} \mathrm{BB})$ but plant protein source decreased ADF comsumption (10.65 $\pm 1.85 \mathrm{~g} / \mathrm{kg} \mathrm{BW}$ ) than with animal protein $(10.82 \pm 1.53 \mathrm{~g} / \mathrm{kg} \mathrm{BW})$. The effect of fermentation on complete feed with rami waste for PE female weaned goat was descented in vivo digestibility of NDF but promoted on ADF, $43.50 \pm 4.92 \%$ without fermentation become $32.58 \pm 3.31 \%$ with fermentation and $25.92 \pm 2.02 \%$ without fermentation became $45.50 \pm 6.15 \%$ with fermentation. The effect of added animal protein decreased on $B K$ in vivo digestibility $(50.83 \pm 2.68 \%)$ than added plant protein $(53.17 \pm 2.35 \%)$. The interaction of both treatment were not significant on consumption and significant on in vivo digestibility of NDF and ADF. Conclusion of the influence of ramie waste with and without fermentation were no effect on consumption but decreasd in vivo digestibility of NDF and increased in ADF that fed

\footnotetext{
${ }^{*}$ Korespondensi (corresponding author):

Telp. +62 81327014293

E-mail: emmy_susanti@yahoo.co.id
} 
by PE female weaned goats. Addition of animal protein in complete feed fed by PE female weaned goats was decented in DM consumption and in vivo digestibility of DM and increased NDF consumption. Interaction of both treatments had effect on digestibility in vivo of $C P$ and $A D F$.

(Key words: Consumption, Fermentation, In vivo digestibility, Protein source, Ramie)

\section{Pendahuluan}

Rami (Boehmeria nivea L Goud) merupakan salah satu tanaman semak yang menghasilkan serat pada bagian kulit batang dengan produksi limbah hijauan tinggi. Daun rami dapat digunakan sebagai pengganti hijauan leguminosa karena kadar protein kasar 22\% (Saroso, 2000) lebih besar dibandingkan dengan rendeng dan daun gamal berturut-turut $15,1 \%$ dan $19,1 \%$ (Hartadi et al., 2005) dengan kandungan serat kasar (SK) tinggi yaitu 37,81\% memungkinkan digunakan sebagai sumber serat (energi) pada pakan ruminansia. Penggunaan limbah batang rami sebagai pakan ternak terkendala oleh rendahnya kecernaan nutrien akibat tingginya kadar serat kasar terlignifikasi sebagai struktur batang.

Produksi dan kualitas nutrisi limbah rami merupakan potensi yang belum dimanfaatkan secara maksimal menjadi pakan ternak terutama sebagai pengganti hijauan. Limbah rami sebagai penyusun complete feed bersama bahan sumber protein nabati atau hewani, bahan sumber energi mudah tercerna serta sumber vitamin B komplek dan mineral. Sumber protein dibedakan atas protein nabati yaitu menir kedelai dan bungkil kedelai dibandingkan sumber protein hewani yaitu tepung ikan. Complete feed dengan sumber protein berbeda mengalami fermentasi dibandingkan dengan tanpa fermentasi. Fermentasi pada complete feed adalah metode sederhana meningkatkan kualitas complete feed untuk penyimpanan dalam waktu lebih lama (Wongnen et al., 2009). Fermentasi secara anaerob meningkatkan kecernaan bahan kering (BK), bahan organik (BO), serat kasar (SK) serta non-structural cabohydrate (Vasupen et al., 2005; 2006) akibat pertumbuhan bakteri asam laktat. Complete feed diberikan pada kambing PE betina lepas sapih untuk mengetahui kualitasnya sebagai pakan dengan mengukur konsumsi dan kecernaannya secara in vivo untuk menjawab tujuan penelitian yaitu mengetahui pengaruh complete feed menggunakan limbah rami dengan atau tanpa fermentasi serta sumber protein nabati atau hewani terhadap kualitas pakan yaitu konsumsi dan kecernaan secara in vivo.

\section{Materi dan Metode}

Materi penelitian adalah complete feed yang menggunakan bahan pakan terdiri dari limbah rami (batang dan daun), gaplek, onggok, bekatul, pollard, menir kedelai, bungkil kedelai, tepung ikan, molases, urea, garam, kapur dan mineralmix. Ransum dengan susunan dan nutriennya tersaji pada Tabel 1.

Dua puluh ekor kambing PE betina lepas sapih (umur 3-4 bulan) dan 24 unit kandang individu yang dilengkapi tempat makan, minum dan perlengkapan uji kecernaan. Bahan kimia dan peralatan analisis $\mathrm{BK}, \mathrm{BO}, \mathrm{PK}, \mathrm{NDF}$ dan $\mathrm{ADF}$, timbangan kapasitas $200 \mathrm{~g}$ dan $20 \mathrm{~kg}$. Metode yang digunakan adalah eksperimental secara in vivo, dengan rancangan dasar penelitian menggunakan Rancangan Acak Lengkap (RAL) pola faktorial $2 \times 2$ dengan 6 (enam) buah ulangan (Steel dan Torrie, 1993). Faktor pertama adalah complete feed tanpa fermentasi $\left(\mathrm{CF}_{0}\right)$ dan dengan fermentasi $\left(\mathrm{CF}_{1}\right)$, sedangkan faktor kedua adalah sumber protein nabati $(\mathrm{N})$ dan hewani $(\mathrm{H})$. Keempat macam perlakuan tersebut yaitu: 1) $\mathrm{CF}_{0} \mathrm{~N}$ adalah complete feed tanpa fermentasi dan sumber protein nabati, 2) $\mathrm{CF}_{0} \mathrm{H}$ adalah complete feed tanpa fermentasi dan sumber protein hewani, 3) $\mathrm{CF}_{1} \mathrm{~N}$ adalah complete feed dengan fermentasi dan sumber protein nabati, 4) $\mathrm{CF}_{1} \mathrm{H}$ adalah complete feed dengan fermentasi dan sumber protein hewani. Data yang diperoleh dianalisis menggunakan analisis ragam mengikuti prosedur general linear models (GLM) pada program SAS versi 6,12 (SAS, 1996). Perlakuan dengan dan tanpa fermentasi serta sumber protein berbeda pada complete feed menggunakan limbah rami yang menunjukkan pengaruh berbeda nyata dilakukan uji lanjut dengan uji Honestly Significant Different (Steel dan Torrie, 1993). 
Tabel 1. Formula dan komposisi nutrien complete feed

(formula and nutrient composition of complete feed)

\begin{tabular}{|c|c|c|c|c|}
\hline \multirow[t]{2}{*}{ Bahan (materials) } & $\mathrm{CF}_{0} \mathrm{~N}$ & $\mathrm{CF}_{1} \mathrm{~N}$ & $\mathrm{CF}_{0} \mathrm{H}$ & $\mathrm{CF}_{1} \mathrm{H}$ \\
\hline & \multicolumn{4}{|c|}{$\%$} \\
\hline Daun rami (ramie leaf) & 13,5 & 13,5 & 13,5 & 13,5 \\
\hline Batang rami (ramie steams) & 16,5 & 16,5 & 16,5 & 16,5 \\
\hline Gaplek (cassava chips) & 10 & 10 & 10 & 10 \\
\hline Onggok (cassava waste) & 10 & 10 & 10 & 10 \\
\hline Bekatul (rice bran) & 9,4 & 9,4 & 14,95 & 14,95 \\
\hline Wheat pollard & 9 & 9 & 9 & 9 \\
\hline Bungkil kedelai (soybean meal) & 10,5 & 10,5 & - & - \\
\hline Menir kedelai (soya waste) & 8,8 & 8,8 & - & - \\
\hline Tepung ikan (fish meal) & - & - & 13,75 & 13,75 \\
\hline Molasses & 10 & 10 & 10 & 10 \\
\hline Urea & 0,3 & 0,3 & 0,3 & 0,3 \\
\hline Garam (salt) & 0,5 & 0,5 & 0,5 & 0,5 \\
\hline Kapur $\left(\mathrm{CaCO}_{3}\right)$ & 0,5 & 0,5 & 0,5 & 0,5 \\
\hline Mineral+Vitamin & 1 & 1 & 1 & 1 \\
\hline Jumlah (total) & 100 & 100 & 100 & 100 \\
\hline \multicolumn{5}{|l|}{ Komposisi kimia (chemical composition) $^{*}$} \\
\hline Abu (\% BK) (ash (\% DM)) & 10,42 & 9,50 & 13,53 & 11,25 \\
\hline Lemak (\% BK) (fat (\% DM)) & 1,93 & 2,51 & 3,31 & 3,42 \\
\hline Serat kasar (\% BK) (crude fiber (\% DM)) & 19,59 & 13,46 & 19,91 & 15,65 \\
\hline $\begin{array}{l}\text { Bahan ekstrak tanpa nitrogen (\% BK) (nitrogen free } \\
\text { extract }(\% D M))\end{array}$ & 48,18 & 52,99 & 41,12 & 49,62 \\
\hline Protein kasar (\% BK) (crude protein $(\% \text { DM) })^{1}$ & 19,88 & 21,54 & 22,13 & 20,07 \\
\hline Total digestible nutrient $(\% \mathrm{BK})^{1}$ & 70,01 & 70,01 & 65,74 & 65,74 \\
\hline
\end{tabular}

$\mathrm{CF}_{0}$ : complete feed menggunakan limbah rami tanpa fermentasi (complete feed using ramie waste without fermentation); $\mathrm{CF}_{1}$ : complete feed menggunakan limbah rami dengan fermentasi (complete feed using ramie waste with fermentation); $\mathrm{N}$ : sumber protein nabati (plant protein source); $\mathrm{H}$ : sumber protein hewani (animal protein source).

* Perhitungan berdasar tabel Hartadi et al. (2005) (calculation based on table Hartadi et al. (2005)).

1 Kebutuhan nutrien kambing perah lepas sapih adalah PK 12,70\% dan TDN 64,81\% (Ranjhan, 1981) (nutrient needs of dairy goats weaning is CP $12.70 \%$ and TDN $64.81 \%$ (Ranjhan, 1981)).

Variabel yang diukur adalah: konsumsi pakan BK, BO, PK (AOAC, 1994), NDF dan ADF (Van Soest, 1982) dan kecernaan pakan secara in vivo (Harris, 1970 cit. Soejono, 1991). Kambing PE betina lepas sapih sebanyak 20 ekor dilakukan penimbangan berat badan, pemberian obat cacing dan vitamin B komplek. Kambing ditempatkan pada kandang individu dan diadaptasikan selama 14 hari untuk penyesuaian dengan sistem pemeliharaan dan jenis pakan baru (preliminary). Selama tahap adaptasi dilakukan pemberian pakan 3,5\% dari berat badan pada pukul 06.30 dan 15.00 WIB, sedangkan air minum diberikan secara ad libitum. Complete feed menggunakan limbah rami dengan fermentasi disiapkan dengan komposisi seperti pada Tabel 1. Kemudian dilakukan fermentasi selama 21 hari dalam keadaan anaerob pada suhu kamar. Complete feed menggunakan limbah rami tanpa fermentasi (Tabel 1) dilakukan pencampuran setiap hari. Pemeliharaan dilakukan selama empat bulan. Setiap dua minggu sekali dilakukan penimbangan berat badan individu (setelah tahap preliminary) untuk mengetahui berat badan, pertambahan berat badan harian dan terkait konsumsi pakan. Penimbangan berat badan dilakukan sebelum pemberian pakan pada pagi hari. Satu minggu terakhir digunakan untuk uji kecernaan secara in vivo (total koleksi).

\section{Hasil dan Pembahasan}

Konsumsi kambing PE betina lepas sapih yang mendapat complete feed menggunakan limbah rami dengan dan tanpa fermentasi serta sumber protein nabati dan hewani tersaji pada Tabel 2.

\section{Konsumsi}

Kambing PE betina lepas sapih yang mendapat complete feed menggunakan 
Tabel 2. Konsumsi complete feed menggunakan limbah rami dengan dan tanpa fermentasi serta sumber protein berbeda pada kambing PE lepas sapih

(complete feed consumption by weaning goat using fermented and unfermented hemp waste, and different protein sources)

\begin{tabular}{|c|c|c|c|c|c|c|}
\hline \multicolumn{3}{|c|}{ Nutrien (nutrient) } & $\begin{array}{l}\text { Sumber protein } \\
\text { (protein sources) }\end{array}$ & $\mathrm{CF}_{0}$ & $\mathrm{CF}_{1}$ & $\begin{array}{l}\text { Rerata } \\
\text { (average) }\end{array}$ \\
\hline \multirow{2}{*}{\multicolumn{3}{|c|}{$\begin{array}{l}\text { Konsumsi BK (g/kg BB) (DM consumption } \\
(g / k g B W))^{n s}\end{array}$}} & $\mathrm{~N}$ & $35,48 \pm 3,61$ & $33,80 \pm 3,32$ & $34,64 \pm 3,47^{a}$ \\
\hline & & & $\mathrm{H}$ & $33,10 \pm 5,31$ & $31,38 \pm 6,38$ & $32,24 \pm 5,85^{b}$ \\
\hline \multicolumn{3}{|l|}{ Rerata (average) } & & $34,29 \pm 4,46$ & $32,59 \pm 4,85$ & \\
\hline \multicolumn{3}{|c|}{$\begin{array}{l}\text { Konsumsi BO (g/kg BB) (OM consumption } \\
(g / \mathrm{kg} \mathrm{BW}))^{\mathrm{ns}}\end{array}$} & $N$ & $33,10 \pm 5,31$ & $33,32 \pm 3,28$ & $33,21 \pm 4,30$ \\
\hline \multicolumn{3}{|l|}{ Rerata (average) } & & $33,91 \pm 3,99$ & $32,25 \pm 4,49$ & \\
\hline \multirow{2}{*}{\multicolumn{3}{|c|}{$\begin{array}{l}\text { Konsumsi PK (g/kg BB) (CP consumption } \\
(g / \mathrm{kg} \mathrm{BW}))^{\mathrm{ns}}\end{array}$}} & $\mathrm{N}$ & $6,60 \pm 0,57$ & $6,82 \pm 0,97$ & $6,71 \pm 0,77$ \\
\hline & & & $\mathrm{H}$ & $6,35 \pm 0,55$ & $6,19 \pm 0,53$ & $6,27 \pm 0,54$ \\
\hline \multicolumn{3}{|l|}{ Rerata (average) } & & $6,48 \pm 0,56$ & $6,51 \pm 0,75$ & \\
\hline Konsumsi NDF $\quad(\mathrm{g} / \mathrm{kg}$ & BB) & $(N D F$ & $\mathrm{N}$ & $12,70 \pm 2,39$ & $8,60 \pm 1,31$ & $10,65 \pm 1,85^{c}$ \\
\hline \multicolumn{3}{|l|}{ consumption $(g / k g B W))^{\mathrm{ns}}$} & $\mathrm{H}$ & $12,83 \pm 1,89$ & $8,80 \pm 1,16$ & $10,82 \pm 1,53^{d}$ \\
\hline \multicolumn{3}{|l|}{ Rerata (average) } & & $12,77 \pm 2,14$ & $8,70 \pm 1,24$ & \\
\hline Konsumsi ADF $\quad(\mathrm{g} / \mathrm{kg}$ & BB) & $(A D F$ & $\mathrm{N}$ & $6,67 \pm 0,76$ & $7,28 \pm 1,68$ & $6,98 \pm 1,22$ \\
\hline \multicolumn{3}{|l|}{ consumption $(g / k g B W))^{n s}$} & $\mathrm{H}$ & $7,67 \pm 0,94$ & $8,40 \pm 2,61$ & $8,04 \pm 1,78$ \\
\hline \multicolumn{3}{|l|}{ Rerata (average) } & & $7,17 \pm 0,85$ & $7,84 \pm 2,15$ & \\
\hline
\end{tabular}

BK: bahan kering (dry matter/DM); BO: bahan organik (organic matter/OM); PK: protein kasar (crude protein/CP); NDF: neutral detergent fiber, ADF: acid detergent fiber.

$\mathrm{CF}_{0}$ : complete feed menggunakan limbah rami tanpa fermentasi (complete feed using ramie waste without fermentation); $\mathrm{CF}_{1}$ : complete feed menggunakan limbah rami dengan fermentasi (complete feed using ramie waste with fermentation); $\mathrm{N}$ : sumber protein nabati (plant protein source); $\mathrm{H}$ : sumber protein hewani (animal protein source).

a,b,c,d Superskrip yang berbeda pada baris/kolom yang sama menunjukkan adanya perbedaan sangat nyata $(P<0,05)$ (different superscript at the same row/column indicate significant differences $(P<0.05)$ ).

ns berbeda tidak berbeda nyata (non significant).

limbah rami dengan dan tanpa fermentasi menunjukkan konsumsi BK, BO, PK, NDF dan ADF tidak berbeda nyata. Penggunaan sumber protein nabati pada complete feed menggunakan limbah rami menunjukkan secara nyata lebih tinggi dibanding dengan sumber protein hewani $(P<0,01)$. Interaksi antara perlakuan dengan atau tanpa fermentasi dan penggunaan sumber protein nabati atau hewani pada complete feed menggunakan limbah rami tidak berpengaruh terhadap konsumsi.

Konsumsi BK. Konsumsi BK pada kambing PE betina lepas sapih yang mendapat complete feed menggunakan limbah rami dengan perlakuan tanpa fermentasi sebesar $34,29 \pm 4,46 \mathrm{~g} / \mathrm{kg} \quad \mathrm{BB}$ sedang dengan pakan fermentasi sebesar $32,59 \pm 4,85 \mathrm{~g} / \mathrm{kg}$ BB. Penggunaan sumber protein nabati dan hewani pada complete feed menggunakan limbah rami berpengaruh nyata pada konsumsi BK $(P<0,05)$. Penggunaan sumber protein nabati yaitu menir kedelai dan bungkil kedelai secara nyata menunjukkan konsumsi BK lebih tinggi $34,64 \pm 3,47 \mathrm{~g} / \mathrm{kg}$ BB dibandingkan dengan kambing yang mendapat protein hewani
$32,24 \pm 5,85 \mathrm{~g} / \mathrm{kg}$ BB. Hal tersebut menunjukkan penggunaan menir kedelai dan bungkil kedelai dalam ransum kambing $P E$ betina lepas sapih lebih disukai kambing dibanding yang mendapat tambahan sumber protein hewani yaitu tepung ikan.

Complete feed menggunakan limbah rami tanpa fermentasi menunjukkan konsumsi BK sebesar $35,48 \pm 3,61 \mathrm{~g} / \mathrm{kg}$ BB $\left(\mathrm{CF}_{0} \mathrm{~N}\right)$ dan $33,10 \pm 5,31 \mathrm{~g} / \mathrm{kg} \quad \mathrm{BB}\left(\mathrm{CF}_{0} \mathrm{H}\right)$ lebih tinggi dibandingkan dengan fermentasi yaitu $33,80 \pm 3,32\left(\mathrm{CF}_{1} \mathrm{~N}\right)$ dan $31,38 \pm 6,38\left(\mathrm{CF}_{1} \mathrm{H}\right)$. Konsumsi BK complete feed menggunakan limbah rami dengan fermentasi menunjukkan nilai yang lebih rendah diduga karena silage memberikan aroma asam-asam organik pada complete feed sedang complete feed tanpa fermentasi lebih menarik aromannya bagi kambing karena adanya aroma tetes. Complete feed menggunakan limbah rami disusun dengan porsi konsentrat $70 \%$. Ransum yang disusun dengan hijauan rendah $(30 \%)$ cenderung produksi propionatnya tinggi sebaliknya bila proporsi hijauan tinggi akan menghasilkan propionat rendah. Pencernaan pakan berserat tinggi menghasilkan proporsi propionat rendah 
dibandingkan degradasi konsentrat (Sutton et al., 2003). Propionat merupakan bahan bakar utama oksidasi di hati dan menjadi pengatur selera makan pada ruminansia (Allen dan Bradfort, 2006). Caldwell et al. (2013), melaporkan pemberian domba dengan crabgrass basah dan kering serta ditambahkan non-viable Lactobacillus acidophilus dan asam laktat menunjukkan konsumsi BK sebesar 18 (crabgrass hay), 23 (crabgrass hay dan disemprot cairan berisi non-viable Lactobacillus dan asam laktat), 23 (crabgrass lembab) dan 22 (crabgrass lembab dan disemprot cairan berisi non-viable Lactobacillus dan asam laktat) $\mathrm{g} / \mathrm{kg} \mathrm{BB}$ $(P>0,05)$.

Interaksi antara perlakuan dengan dan tanpa fermentasi dan penggunaan sumber protein nabati dan hewani pada complete feed menggunakan limbah rami tidak berpengaruh nyata terhadap konsumsi BK kambing PE betina lepas sapih.

Konsumsi BO. Pengaruh perlakuan tanpa dan dengan fermentasi pada complete feed menggunakan limbah rami terhadap konsumsi BO kambing PE betina lepas sapih tidak berbeda nyata. Konsumsi $\mathrm{BO}$ pada complete feed tanpa fermentasi adalah $33,10 \pm 5,31 \mathrm{~g} / \mathrm{kg}$ BB $\left(\mathrm{CF}_{0} \mathrm{~N}\right)$ dan $34,72 \pm 2,67$ $\mathrm{g} / \mathrm{kg} \mathrm{BB}\left(\mathrm{CF}_{0} \mathrm{H}\right)$ sedangkan complete feed yang mengalami fermentasi yaitu $33,32 \pm 3,28$ $\mathrm{g} / \mathrm{kg}$ BB $\left(\mathrm{CF}_{1} \mathrm{~N}\right)$ dan $31,18 \pm 5,70 \mathrm{~g} / \mathrm{kg}$ BB $\left(\mathrm{CF}_{1} \mathrm{H}\right)$. Konsumsi $\mathrm{BO}$ menunjukkan nilai yang lebih tinggi pada complete feed tanpa fermentasi, 33,91 \$3,99 g/kg BB dibandingkan dengan fermentasi, 32,25 $\pm 4,49 \mathrm{~g} / \mathrm{kg}$ BB. Konsumsi BO pada complete feed menggunakan limbah rami tanpa fermentasi yang lebih tinggi karena aroma asam-asam organik yang terbentuk selama proses fermentasi kurang disukai kambing PE betina lepas sapih.

Konsumsi BO pada complete feed menggunakan limbah rami yang mendapat tambahan sumber protein berbeda pada kambing PE betina lepas sapih menunjukkan pengaruh tidak berbeda nyata. Konsumsi BO complete feed yang mendapat protein nabati sebesar 33,21 $\pm 4,30 \mathrm{~g} / \mathrm{kg}$ BB sedangkan yang mendapat complete feed dengan limbah rami dan sumber protein hewani sebesar $32,95 \pm 4,19 \mathrm{~g} / \mathrm{kg}$ BB. Interaksi perlakuan tanpa dan dengan fermentasi bersama perlakuan penggunaan sumber protein berbeda terhadap konsumsi BO juga tidak berbeda nyata.
Konsumsi PK. Kambing PE betina lepas sapih yang mengkonsumsi complete feed menggunakan limbah rami tanpa dan dengan fermentasi menunjukkan konsumsi PK tidak berbeda nyata. Besaran konsumsi PK kambing PE yang mendapat complete feed menggunakan limbah rami dengan fermentasi adalah 6,48 $0,56 \mathrm{~g} / \mathrm{kg} \quad \mathrm{BB}$ sedangkan yang mendapat complete feed menggunakan limbah rami dengan fermentasi

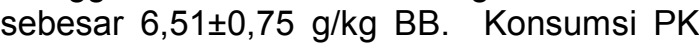
kambing PE betina lepas sapih yang mendapat complete feed menggunakan limbah rami yang mendapat sumber protein asal nabati sebesar $6,71 \pm 0,77 \mathrm{~g} / \mathrm{kg} \quad \mathrm{BB}$ sedang yang mendapat complete feed menggunakan limbah rami dengan sumber protein asal hewani sebesar $6,27 \pm 0,54 \mathrm{~g} / \mathrm{kg}$ BB juga menunjukkan pengaruh tidak berbeda nyata. Interaksi kedua perlakuan terhadap konsumsi PK kambing PE betina lepas sapih tidak berbeda nyata.

Konsumsi NDF. Konsumsi kambing PE betina lepas sapih pada NDF dari complete feed menggunakan limbah rami dengan dan tanpa fermentasi tidak berbeda nyata. Konsumsi NDF pada complete feed tanpa fermentasi sebesar $12,77 \pm 2,14 \mathrm{~g} / \mathrm{kg} \mathrm{BB}$ sedang dengan fermentasi sebesar $8,70 \pm 1,24$ $\mathrm{g} / \mathrm{kg} \mathrm{BB}$. Konsumsi NDF dari kambing PE betina lepas sapih yang mendapat complete feed menggunakan limbah rami dan sumber protein berbeda menunjukkan pengaruh berbeda nyata $(P<0,05)$. Konsumsi NDF pada complete feed dengan sumber protein nabati $10,65 \pm 1,85 \mathrm{~g} / \mathrm{kg}$ BB secara nyata lebih rendah dibandingkan yang mendapat complete feed dengan sumber protein hewani yaitu 10,82 $\pm 1,53 \mathrm{~g} / \mathrm{kg}$ BB. Domba yang mendapat pakan menggunakan rumput, daun rami, dedak dan disupplementasi $\mathrm{Cu}, \mathrm{P}$ dan methionin menunjukkan konsumsi NDF

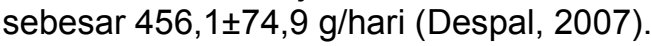

Konsumsi ADF. Kambing PE betina lepas sapih yang mendapat complete feed menggunakan limbah rami tanpa dan dengan fermentasi pada keempat perlakuan tidak berbeda terhadap konsumsi ADF kambing PE betina lepas sapih yaitu $7,17 \pm 0,85 \mathrm{~g} / \mathrm{kg} \mathrm{BB}$ pada konsumsi complete feed tanpa fermentasi sebaliknya dengan fermentasi sebesar 7,84 $\pm 2,15 \mathrm{~g} / \mathrm{kg}$ BB. Pengaruh penggunaan sumber protein nabati dan hewani dalam complete feed menggunakan limbah rami terhadap konsumsi ADF kambing PE betina lepas sapih juga tidak berbeda 
nyata. Konsumsi ADF tersebut untuk complete feed dengan protein nabati asal menir kedelai dan bungkil kedelai adalah $6,98 \pm 1,22 \mathrm{~g} / \mathrm{kg}$ BB. Interaksi kedua perlakuan pada konsumsi ADF kambng PE betina lepas sapih juga tidak berbeda nyata yaitu $6,67 \pm 0,76 \quad\left(\mathrm{CF}_{0} \mathrm{~N}\right), \quad 7,67 \pm 0,94 \quad\left(\mathrm{CF}_{0} \mathrm{H}\right)$, $7,28 \pm 1,68\left(\mathrm{CF}_{1} \mathrm{~N}\right)$ dan $8,40 \pm 2,61\left(\mathrm{CF}_{1} \mathrm{H}\right) \mathrm{g} / \mathrm{kg}$ BB.

\section{Kecernaan nutrien secara in vivo}

Kecernaan in vivo dari complete feed menggunakan limbah rami dengan dan tanpa fermentasi serta sumber protein nabati dan hewani pada kambing PE betina lepas sapih selengkapnya tersaji pada Tabel 3.

Perlakuan complete feed menggunakan limbah rami dengan fermentasi menurunkan kecernaan in vivo NDF tetapi menaikkan kecernaan in vivo ADF dibandingkan tanpa ensilage pada kambing PE betina lepas sapih $(P<0,01)$. Perlakuan penggunaan sumber protein berbeda pada kambing yang mengkonsumsi complete feed menggunakan limbah rami menunjukkan hasil berbeda nyata terhadap kecernaan BK secara in vivo $(P<0,05)$. Pengaruh interaksi kedua perlakuan terhadap kecernaan PK secara in vivo berbeda nyata $(P<0,05)$ dan terhadap kecernaan ADF secara in vivo berbeda sangat nyata $(P<0,01)$ pada kambing $P E$ betina lepas sapih.

\section{Kecernaan $\mathrm{BK}$ secara in vivo}

Kecernaan BK secara in vivo menunjukkan sejumlah bahan kering yang mampu diserap saluran cerna kambing PE betina lepas sapih yang mendapat complete feed nabati maupun hewani baik dengan perlakuan tanpa dan dengan fermentasi maupun dengan penggunaan sumber protein berbeda. Kecernaan BK secara in vivo dari kambing PE yang mendapat complete feed menggunakan limbah rami tanpa dan dengan fermentasi tidak berbeda nyata.

Perlakuan penggunaan sumber protein berbeda terhadap kecernaan BK secara in vivo pada kambing $\mathrm{PE}$ betina lepas sapih yang mengkonsumsi complete feed menggunakan limbah rami menunjukkan hasil

Tabel 3. Kecernaan in vivo pada complete feed menggunakan limbah rami dengan dan tanpa fermentasi serta sumber protein berbeda pada kambing PE betina lepas sapih

(complete feed in vivo digestibility by weaning goat using fermented and unfermented hemp waste, and different protein sources)

\begin{tabular}{|c|c|c|c|c|}
\hline Nutrien (nutrient) & $\begin{array}{c}\text { Sumber protein } \\
\text { (protein } \\
\text { sources) }\end{array}$ & $\mathrm{CF}_{0}$ & $\mathrm{CF}_{1}$ & $\begin{array}{c}\text { Rerata } \\
\text { (average) }\end{array}$ \\
\hline \multirow[t]{2}{*}{ Kecernaan BK (\%) (DM digestibility (\%)) $)^{\mathrm{ns}}$} & $\mathrm{N}$ & $53,00 \pm 2,28$ & $53,33 \pm 2,42$ & $53,17 \pm 2,35^{a}$ \\
\hline & $\mathrm{H}$ & $50,33 \pm$ & 86 & $50,83 \pm 2,68^{b}$ \\
\hline Rerata (average) & & $51,67 \pm 2,89$ & $52,33 \pm 2,14$ & \\
\hline \multirow[t]{2}{*}{ Kecernaan BO (\%) (OM digestibility (\%) $)^{\mathrm{ns}}$} & $\mathrm{N}$ & $54,67 \pm 3,39$ & $56,17 \pm 2,32$ & $55,42 \pm 2,86$ \\
\hline & $\mathrm{H}$ & $56,17 \pm 5,15$ & $56,83 \pm 1,33$ & $56,50 \pm 3,24$ \\
\hline Rerata (average) & & $2,14 \pm 4,27$ & $56,50 \pm 1,83$ & \\
\hline \multirow{2}{*}{ Kecernaan PK $(\%)(C P \text { digestibility }(\%))^{\mathrm{s}}$} & $\mathrm{N}$ & $52,17 \pm 2$ & $58,33 \pm 2,87$ & $55,25 \pm 2,51$ \\
\hline & $\mathrm{H}$ & $54,83 \pm 6,18$ & $53,17 \pm 1,94$ & $54,00 \pm 4,06$ \\
\hline Rerata (average) & & $53,50 \pm 4,16$ & $55,75 \pm 2,41$ & \\
\hline \multirow{2}{*}{$\begin{array}{l}\text { Kecernaan NDF (\%) (NDF digestibility } \\
(\%))^{\mathrm{ns}}\end{array}$} & $\mathrm{N}$ & $41,17 \pm 2,23$ & $33,33 \pm 3,50$ & $37,25 \pm 2,87$ \\
\hline & $\mathrm{H}$ & $45,83 \pm 7,60$ & $31,83 \pm 3,12$ & $38,83 \pm 5,36$ \\
\hline & & $43,50 \pm 4,92^{\mathrm{c}}$ & $32,58 \pm 3,31^{d}$ & \\
\hline \multirow[t]{2}{*}{ Kecernaan ADF (\%) (ADF digestibility (\%) $)^{\mathrm{s}^{*}}$} & $\mathrm{~N}$ & $29,00 \pm 3,29$ & $40,83 \pm 4,96$ & $34,92 \pm 4,13$ \\
\hline & $\mathrm{H}$ & $22,83 \pm C$ & $50,17 \pm 7,33$ & $36,50 \pm 4,04$ \\
\hline \multicolumn{2}{|l|}{ Rerata (average) } & $25,92 \pm 2,02^{\mathrm{e}}$ & $45,50 \pm 6,15^{f}$ & \\
\hline \multicolumn{5}{|c|}{ 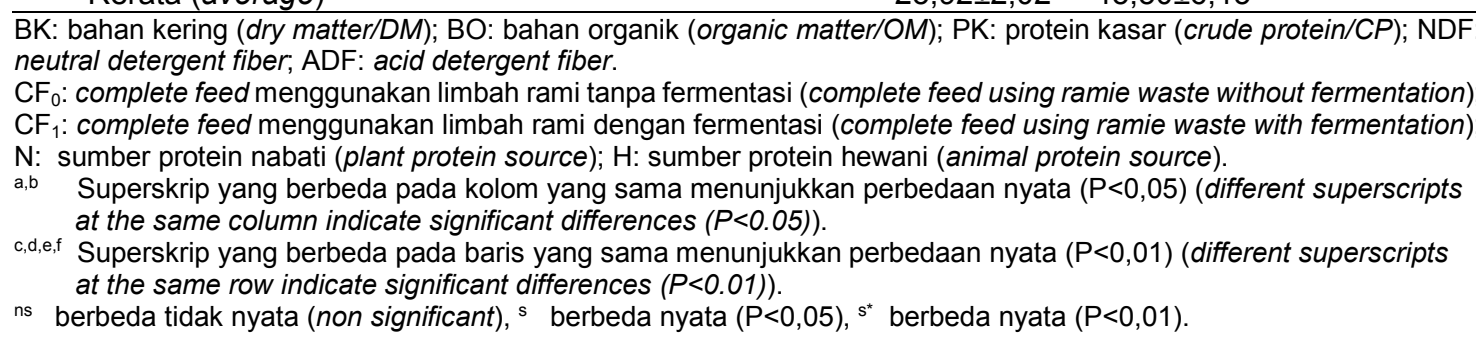 } \\
\hline
\end{tabular}


berbeda nyata $(P<0,05)$. Kecernaan BK secara in vivo pada kambing $\mathrm{PE}$ betina lepas sapih yang mengkonsumsi complete feed menggunakan limbah rami adalah $53,17 \pm 2,35$ pada complete feed dengan sumber protein nabati yang secara nyata lebih tinggi dibanding yang mendapat sumber protein

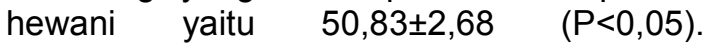
Kecernaan in vivo BK bagi kambing $\mathrm{PE}$ betina lepas sapih yang mendapat complete feed menggunakan limbah rami dan sumber protein menir kedelai dan bungkil kedelai menunjukkan nilai yang lebih tinggi dari pada yang mendapat tepung ikan. Protein pada menir kedelai dan bungkil kedelai lebih mudah didegradasi oleh mikrobia rumen kambing PE betina lepas sapih karena mempunyai persentase sistein yang lebih sedikit dibanding tepung ikan. Komposisi asam amino lysin, metionin dan cystine pada tepung ikan lebih tinggi dari pada biji kedelai dan bungkil kedelai yaitu 6,9-7,94 g/16 g N; 2,62,95 g/16 g N dan 0,79-0,97 g/16 g N pada tepung ikan (IAFMM, 1970).

Interaksi perlakuan tanpa dan dengan fermentasi serta penggunaan sumber protein berbeda pada kambing PE betina lepas sapih yang mendapat complete feed menggunakan limbah rami menunjukkan tidak berbeda nyata.

\section{Kecernaan BO secara in vivo}

Kecernaan $\mathrm{BO}$ secara in vivo pada kambing PE betina lepas sapih yang mengkonsumsi complete feed menggunakan limbah rami menunjukkan respon tidak nyata sebagai akibat perlakuan tanpa dan dengan fermentasi, penggunaan sumber protein nabati dan hewani serta interaksi kedua perlakuan. Nilai kecernaan $\mathrm{BO}$ secara in vivo adalah $54,67 \pm 3,39$ pada $\mathrm{CF}_{0} \mathrm{~N} ; 56,17 \pm 5,15$ pada $\mathrm{CF}_{0} \mathrm{H} ; 56,17 \pm 2,32$ pada $\mathrm{CF}_{1} \mathrm{~N}$ dan $56,83 \pm 1,33$ pada $\mathrm{CF}_{1} \mathrm{H}$.

\section{Kecernaan PK secara in vivo}

Kecernaan PK secara in vivo pada kambing $P E$ betina lepas sapih yang mendapat complete feed menggunakan limbah rami sebagai pengaruh perlakuan tanpa dan dengan fermentasi dan perlakuan penggunaan sumber protein berbeda menunjukkan hasil tidak berbeda nyata. Nilai kecernaan $\mathrm{PK}$ secara in vivo adalah $52,17 \pm 2,14$ pada $\mathrm{CF}_{0} \mathrm{~N} ; 54,83 \pm 6,18$ pada $\mathrm{CF}_{0} \mathrm{H} ; 58,33 \pm 2,87$ pada $\mathrm{CF}_{1} \mathrm{~N}$ dan $53,17 \pm 1,94$ pada $\mathrm{CF}_{1} \mathrm{H}$. Pengaruh interaksi kedua perlakuan pada kambing PE betina lepas sapih yang mengkonsumsi complete feed menggunakan limbah rami terhadap kecernaan PK secara in vivo berbeda nyata $(P<0,05)$. Perlakuan fermentasi pada complete feed menggunakan limbah rami dan sumber protein nabati asal menir kedelai dan bungkil kedelai menunjukkan nilai kecernaan PK secara in vivo paling besar. Proses fermentasi berakibat penurunan $\mathrm{pH}$ complete feed menggunakan limbah rami dan sumber protein nabati mencapai $4,99 \pm 0,36$ yang dalam rentang aktivitas enzim proteolitik sehingga protein terdegradasi menjadi asam amino yang siap dicerna. Asam amino dalam menir kedelai maupun bungkil kedelai relatif lebih mudah didegradasi dibandingkan asam amino dalam tepung ikan. Hal tersebut kemungkinan disebabkan oleh konsentrasi sistein dalam tepung ikan lebih tinggi dan merupakan peptida dengan ikatan kovalen antara dua gugus sulfurnya. Dua molekul cystine yang membentuk systein dengan ikatan disulfida pada gugus sulfurnya menjadikan kurang dapat digunakan oleh bakteri penghasil asam asetat yang aktivitasnya berlangsung singkat pada awa kondisi anaerob pada hari kedua sampai ketiga dalam proses fermentasi (MohdSetapar et al., 2012).

\section{Kecernaan NDF secara in vivo}

Kecernaan NDF pada complete feed menggunakan limbah rami tanpa fermentasi sebesar $43,50 \pm 4,92$ secara nyata lebih tinggi dari pada dengan fermentasi yaitu $32,58 \pm 3,31(P<0,01)$. Complete feed tersusun oleh lebih banyak materi berbentuk mash yang menjadikannya segera meninggalkan rumen sehingga kesempatan mencerna komponen NDF menjadi lebih singkat. Kecepatan meninggalkan rumen pada hijauan lebih lambat dari pada konsentrat (Huftanen dan Kukkonen,1995; Stensig et al., 1997 cit. Hvelplund dan Weisbjerg, 2000). Kecernaan NDF pada kambing PE betina lepas sapih tersebut mendekati kajian Samanta et al. (2003). Kecernaan NDF pada complete feed dengan mustard cake yang disubstitusi $15 \%$ dan $30 \%$ tepung daun lamtoro dan dicobakan pada kambing Barbari sebesar $49,87 \%$ dan 47,61\% $\quad(P>0,05)$ (Samanta et al., 2003). Domba kebiri yang mendapat silage complete feed, silage complete feed dengan substitusi 30\% ampas tahu kering, 30\% dedak padi dan 30\% limbah 
teh hijau basah berpengaruh nyata pada kecernaan NDF sebesar 65,8\%; 72,0\%; 64,2\% dan 63,1\% (Cao et al., 2009).

Kambing PE betina lepas sapih yang mengkonsumsi complete feed menggunakan limbah rami dan mendapat tambahan sumber protein nabati dan hewani berpengaruh tidak nyata terhadap kecernaan NDF secara in vivo. Interaksi perlakuan tanpa dan dengan fermentasi dan perlakuan penggunaan sumber protein berpengaruh berbeda tidak nyata terhadap kecernaan NDF secara in vivo pada kambing PE betina lepas sapih.

\section{Kecernaan ADF secara in vivo}

Kambing PE betina lepas sapih yang mendapat complete feed menggunakan limbah rami dengan perlakuan tanpa dan dengan fermentasi berpengaruh nyata pada kecernaan ADF secara in vivo $(P<0,01)$. Persentase kecernaan ADF secara in vivo dari complete feed menggunakan limbah rami dengan fermentasi menunjukkan 25,92 $\pm 2,02$ lebih rendah dibandingkan dengan complete feed yang mengalami fermentasi yaitu

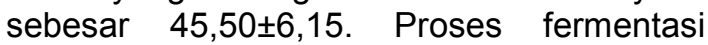
secara nyata meningkatkan kecernaan ADF secara in vivo. Proses fermentasi yang bersuasana asam dan dilanjutkan pencernaan enzimatis dalam rumen mampu melabilkan ikatan kimiawi komponen ADF. Complete feed dengan mustard cake yang disubstitusi $15 \%$ dan $30 \%$ tepung daun lamtoro menunjukkan kecernaan ADF pada kambing Barbari sebesar $46,41 \%$ dan $44,05 \%$ (P>0,05) (Samanta et al., 2003). Kecernaan ADF pada complete feed menggunakan biji kapok utuh dan pecah tanpa fermentasi yang diberikan pada sapi perah sebesar $54,9 \%$ dan $54,4 \%$ sedang yang mengalami fermentasi sebesar $55,2 \%$ dan $60,7 \% \quad(P>0,05)$ (Wongnen et al., 2009).

Kambing PE betina lepas sapih yang mendapat complete feed menggunakan limbah rami dengan penggunaan sumber protein nabati dan hewani tidak menunjukkan pengaruh nyata pada kecernaan ADF secara in vivo. Nilai kecernaan ADF secara in vivo adalah $29,00 \pm 3,29 \%$ pada $\mathrm{CF}_{0} \mathrm{~N}$; $40,83 \pm 4,96 \%$ pada $\mathrm{CF}_{1} \mathrm{~N} ; 22,83 \pm 0,75 \%$ pada $\mathrm{CF}_{0} \mathrm{H}$ dan $50,17 \pm 7,33 \%$ pada $\mathrm{CF}_{1} \mathrm{H}$.

Kambing PE betina lepas sapih yang mendapat perlakuan tanpa dan dengan fermentasi dan penggunaan sumber protein berbeda menunjukkan adanya interaksi kedua perlakuan pada kecernaan ADF secara in vivo $(\mathrm{P}<0,01)$. Kecernaan ADF secara in vivo pada complete feed menggunakan limbah rami menunjukkan interaksi kedua perlakuan tanpa dan dengan fermentasi dan penggunaan sumber protein berbeda dengan nilai tertinggi pada $\mathrm{CF}_{1} \mathrm{H}(50,17 \pm 7,33 \%)$. Hal tersebut menunjukkan proses fermentasi terhadap complete feed yang menggunakan sumber protein tepung ikan mampu mencapai $\mathrm{pH}$ optimal aktivitas enzim proteolitik dan selulolitik $\left(\mathrm{pH}\right.$ akhir fermentasi $\mathrm{CF}_{1} \mathrm{H}$ adalah $4,61 \pm 0,09)$. Proses penurunan $\mathrm{pH}$ berakibat pada aktivasi enzim selulolitik sehingga menguraikan selulosa menjadi gula yang mudah tercerna. Selulosa merupakan salah satu komponen dalam ADF. Penurunan serat pada silage terkait dengan aktivitas enzim proteolitik dan fibrolitik dari mikrobia dan tanaman (Kung et al., 2000; Nadeau et al., 2000). Enzim-enzim tersebut bersifat labil pada suasana asam dengan aktivitas optimum pada pH 5-6 (McDonald, 1981). Komponen ADF adalah selulosa, lignin dan Si (Prawirokusumo, 1994).

\section{Kesimpulan}

Kambing PE betina lepas sapih yang mendapat complete feed menggunakan limbah rami fermentasi menunjukkan penurunan NDF sebaliknya meningkatkan kecernaan in vivo ADF. Pemberian complete feed menggunakan limbah rami dengan sumber protein hewani menurunkan konsumsi BK, menaikkan konsumsi NDF dan menurunkan kecernaan BK sedangkan interaksi kedua perlakuan berpengaruh pada kecernaan PK dan ADF.

\section{Ucapan Terima Kasih}

Ucapan terima kasih disampaikan kepada Dirjen Dikti atas didanainya penelitian ini melalui Hibah Disertasi Doktor 2014 dan kepada Prof. Dr. Ir. Ali Agus, DAA. DEA. selaku promotor dan Ir. Yustina Yuni Suranindyah, M.Sc. Ph.D. selaku kopromotor yang telah membimbing pelaksanaan penelitian.

\section{Daftar Pustaka}

Allen, M. S. and B. J. Bradford. 2006 Metabolic regulation of food intake in ruminants. J. Anim. Sci. 84: 120-121.

AOAC. 1994. Official Methods of Analysis. Association of Official Agricultural Chemists. Agricultural Chemicals; Contaminants and Drugs. Vol 2. 
Association of Official Agricultural Chemists. Inc., Virginia.

Caldwell, J. D., D. Philipp, K. P. Coffey, L. A. Hardinas, A. E. Bass, A. N. Young, R. T. Rhein and W. K. Coblentz. 2013. Intake and digestibility by sheep, in situ disappearance in cannulated cows, and chemical composition of crabgrass hayed at two moisture concentrations and treated with a non-viable Lactobacillus-lactic acid additive. Anim. Feed Sci. Technol. 186: 27-35.

Cao, Y., T. Takahashi and K. Horiguchi. 2009. Effects of addition of food by-products on the fermentation quality of a total mixed ration with whole crop rice and its digestibility, preference, and rumen fermentation in sheep. Anim. Feed Sci. Technol. 151: 1-11.

Despal. 2007. Suplementasi nutrien defisien untuk meningkatkan penggunaan daun rami (Boehmeria nivea, L. Gaud) dalam ransum domba. Media Peternakan 30: 181-188.

Hartadi, H., S. Reksohadiprodjo, dan A. D. Tillman. 2005. Tabel Komposisi Pakan untuk Indonesia. Gajah Mada Press, Yogyakarta.

Hvelplund, T. and M. R. Weisbjerg. 2000. In Situ techniques for the estimation of protein degradability and postrumen availability. In: Forage Evaluation in Ruminants Nutrition. D. I. Givens, E. Owen, R. F. E. Oxford and H. M. Omed (eds). $\quad \mathrm{CABI}$ Publishing. CAB International, Wallingford, UK, pp. 237.

IAFMM, 1970. Available amino acid content of fish meals. Hertfordshire. FAO, Rome.

Kung, Jr. L., J. R. Robinson, N. K. Ranjit, J. H. Chen, C.M. Golt and C. D. Pesek. 2000. Microbial populations, fermentation end products and aerobic stability of corn silage treated with ammonia or a propionic acid-based preservative. J. Dairy Sci. 83: 14791486.

McDonald, P., A. R. Henderson and S. J. E. Heron. 1981. Biochemistry of Silage. 2nd. Chalcombe Publications. Marlow, UK, pp. 184.

Mohd-Setapar, S. H., N. Abd-Talib and R. Aziz. 2012. Review on crucial parameters of silage quality. SciVerse Science Direct. APCBEE Procedia 3: 99-103.
Nadeau, E. M., G. D. R. Buxton, J. R. Russel. M. J. Allison and J. W. Young. 2000. Enzyme, bacterial inoculant and formic acid effects on silage composition of orchard grass and alfalfa. J. Dairy Sci. 83: $1487-1492$

Prawirokusumo, S. 1994. IImu Gizi Komparatif. Edisi ke-1. BPFE, Yogyakarta.

Ranjhan, S. K. 1981. Animal Nutrition in the Tropics. 2nd Revised Edition. Vikas Publishing House PVT. LTD, New Delhi, pp. 323.

Samanta, A. K., K. K. Singh, M. M. Das, S. B. Maity and S. S. Kundu. 2003. Effects of complete feed block on nutrient utilisation and rumen fermentation in Barbari goats. Small Rumin. Res. 48: 95-102.

Saroso, B. 2000. Rami (Boehmeria nivea Gaud) Penghasil Bahan Tekstil, Pulp dan Pakan Ternak. AGRIS RecordFAO of the United Nation, Bogor.

SAS. 1996. SAS/STAT user's guide (Release 6.12). SAS Inst. Inc., Cary, NC.

Steel, R. G. D. and J. H. Torrie. 1993. Principles and Procedures of Statistics. Mc Graw-Hill Book Co. Inc. Pub. Ltd, London.

Sutton, J. D., M. S. Dhanoa, S. V. Morant, J. France, D. J. Napper and E. Schuller. 2003. Rates of production of acetat, propionat and butyratein the rumen of lactating dairy cows given normal and low roughage diets. J. Dairy Sci. 86: 3620-3633.

Van Soest, P. J. 1982. Nutritional Ecology of the Ruminant. $\mathrm{O}$ and B. Book Inc., Corvallis Oregon.

Vasupen, K., C. Yuangklang, S. Witayakun and Srinanuan. 2005. Effect of difference moisture on quality of fermented total mixed ration. In: Proceeding of the Technical Conference of $43^{\text {th }}$. Kasetsart University, Bangkok.

Vasupen, K., C. Yuangklang, C. Sarnklong, S. Wongsuthavas, J. Matchaothai and P. Srenanul. 2006. Effects of total mixed ration and fermented total mixed ration on voluntary feed intake, digestion nutrition digestibility and milk production in lactating dairy cows. In: Proceedings of the Technical Conference of $44^{\text {th }}$. Kasetsart University, Bangkok. 
Wongnen, C., C. Wachirapakorn, C. Patipan, D. Panpong, K. Kongweha, N. Namsaen, P. Gunun and C. Yuangklang. 2009. Effects of fermented total mixed ration and cracked cottonseed on milk yield and milk composition in dairy cows. Asian-Aust. J. Anim. Sci. 22: 1625-1632. 